ISSN: 2302-8556

E-Jurnal Akuntansi Universitas Udayana

Vol.24.2.Agustus (2018): 1274-1300

DOI: https://doi.org/10.24843/EJA.2018.v24.i02.p17

\title{
Pengaruh Human Capital Pada Nilai Perusahaan dengan Corporate Governance Sebagai Variabel Pemediasi
}

\author{
Kadek Virna Purwita Sari ${ }^{1}$ \\ Herkulanus Bambang Suprasto ${ }^{2}$
}

${ }^{1}$ Fakultas Ekonomi dan Bisnis Universitas Udayana (Unud), Bali, Indonesia
email: virnapurwita.s @ gmail.com / telp: +6282247103034
${ }^{2}$ Fakultas Ekonomi dan Bisnis Universitas Udayana (Unud), Bali, Indonesia

\begin{abstract}
ABSTRAK
Perusahaan mempunyai tujuan utama untuk meningkatkan kesejahteraan pemegang saham dengan memaksimalkan nilai perusahaan, dengan adanya sumber daya (human capital) yang baik dalam perusahan. Penerapan good corporate governance yang sesuai dengan aturan yang berlaku akan memberikan peningkatan kinerja perusahaan (human capital) dan akan berdampak langsung pada peningkatan nilai perusahaan. Penelitian ini bertujuan untuk mendapatkan bukti empiris mengenai pengaruh human capital pada nilai perusahaan melalui corporate governance sebagai pemediasi pada tahun 20092016. Metode penentuan sampel yang digunakan dalam penelitian adalah metode purposive sampling. Jumlah perusahaan yang memenuhi kriteria adalah 8 perusahaan dengan 136 pengamatan. Pengumpulan data dilakukan dengan metode observasi non partisipan. Teknik analisis data yang digunakan yaitu uji analisis Path. Hasil pengujian tidak menunjukkan bahwa corporate governance mampu memediasi pengaruh human capital pada nilai perusahaan.
\end{abstract}

Kata kunci:Nilai perusahaan, human capital, corporate governance.

\begin{abstract}
The company has the main goal to improve the welfare of shareholders by maximizing the value of the company, with the existence of good human capital in the company. Implementation of good corporate governance in accordance with applicable rules will provide an increase in company performance (human capital) and will have a direct impact on the increase in corporate value. This study aims to obtain empirical evidence on the influence of human capital on corporate value through corporate governance as a mediator in 2009-2016. Sample determination method used in this research is purposive sampling method. The number of companies that meet the criteria are 8 companies with 136 observations. Data collection was done by non participant observation method. Data analysis technique used is Path analysis test. The test results do not show that corporate governance is able to mediate the influence of human capital on firm value.
\end{abstract}

Keywords:Firm value, human capital, corporate governance. 


\section{PENDAHULUAN}

Memaksimalkan nilai perusahaan merupakan tujuan jangka panjang pendirian sebuah perusahaan(Rasyid, 2015). Nilai perusahaan merupakan suatu proksi yang menggambarkan kemakmuran pemegang saham (Sartono, 2002). Perhatian terhadap nilai perusahaaan dianggap sangat penting karena mencerminkan kinerja perusahaan dan harga saham yang dapat mempengaruhi persepsi investor terhadap perusahaan tersebut. Keadaan suatu perusahaan, baik kinerja saat ini maupun keadaan masa depannya dapat dinilai secara kolekif oleh investor melalui nilai perusahaan (Brealey et al., 2008). Nilai perusahaan yang baik dapat direfleksikan berdasarkan harga pasar saham perusahaan yang baik juga. Memaksimalkan nilai pada perusahaan merupakan suatu cara yang dapat dilakukan untuk dapat mebingkatkan kekayaan pemegang saham (Keown dan John, 2011:240). Ketika nilai perusahaan dikatakan meningkat, maka kesejahteraan pemegang saham tersebut akan ikut meningkat, hal tersebut terlihat dari return saham bagi investor. Nilai perusahaan dapat memberikan dampak yang baik terhadap kemakmuran pemegang saham secara maksimum apabila harga saham tersebut meningkat. Nurlela dan Islahuddin (2008) menyatakan bahwa prinsip penting menurut investor sebagai indikator dalam menilai seluruh perusahaan adalah nilai perusahaan (firm value )atau dikenal sebagai Enterprise Value (EV).

Suatu keadaaan di Bursa Efek Indonesia yang menggambarkan bahwa nilai perusahaan dari perusahaan manufaktur yang diproksikan oleh nilai tobin's $q$ telah berfluktuasi dari tahun ke tahun. Banyaknya faktor-faktor penyebab yang dapat mempengrauhi nilai perusahaan seperti penelitian yang dilakukan oleh Dwi Sukirni 
ISSN: 2302-8556

E-Jurnal Akuntansi Universitas Udayana Vol.24.2.Agustus (2018): 1274-1300

(2012), Azhari Hidayat (2013), dan Siti (2013) menyatakan bahwa profitabilitas, ukuran perusahaan, dan kebijakan hutang dapat mempengaruhi nilai dari peruahaan.

Intellectual capital masihkurang diketahui secara keseluruhan dalam banyak kasus yang ada di Indonesia, sehinga menyebabkan banyak perusahaan di Indonesia yang cenderung masih memanfaatkan conventional based dalam mendirikan bisnisnya, hingga kandungan teknologi di dalam produk yang dihasilkan masih cenderung rendah dan perusahaan-perusahaan tersebut belum memberikan perhatian lebih terhadap sumber daya perusahaan seperti capital employed, human capital, dan structural capital (Pornpen, 2014). Berdasarkan fungsinya sumber daya tersebutmerupakan bagian dari pembangunan modal intelektual perusahaanyang memiliki pengaruh yang kuat dalam menciptkan nilai dari perusahaan (Tjiptohadi, 2003). Teori RBT menjelaskan tentang kinerja perusahaan akan optimal jika perusahaan memiliki keunggulan kompetitif sehingga dapat menghasilkan nilai bagi perusahaan.

Kuryanto (2008) menyatakan bahwa keunggulan kompetitif dihasilkan dari kemampuan perusahaan dalam mengelola sumber dayanya dengan baik sehingga dapat menciptakan value added bagi perusahaan. Pemimpin perusahaan banyak yang kurang mengetahui bahwa faktor produksi utama yang menyebabkan perusahaan memperoleh keuntungan dari sumber daya manusia atau human capital. Faktor produksi seperti modal, uang, dan teknologi lebih di utamakan dibandingkan dengan sumber daya manusianya.Mayo (2000), menyatakan terdapat lima komponendari sumber daya manusia atau human capital dan komponen tersebut mempunyai peran 
yang untuk dapat membentuk human capital di perusahaan yang nantinya akan dapat meningkatkan nilai dari perusahaan. Komponen tersebut terdiri dariindividual capability, individual motivation, leadership, the organizational climate, dan workgroup effectiveness.

Semakin majunyalingkungan bisnis,semakin banyak juga perusahaanyang tergantung pada intangible asset daripada tangible asset. Harahap berpendapat bahwa banyak pihak yang meyakini aset paling berharga di suatu perusahaan ialah bersumber dari intangible asset perusahaan berupa sumber daya manusia (SDM), karena tangible asset yang ada pada perusahaan harus dikendalikan oleh sumber daya manusia yang ada. Laporan keuangan yang belum dapat memberikan informasi mengenai sumber daya manusia telah menjadi kelemahan perusahaan.

Penelitian yang dilakukan oleh Wealtherly (2003) menyatakan penilaian human capital memiliki peran penting di dalam komunitas bisnis yang memiliki dua kekuatan utama. Kekuatan pertama adalah adanya globalisasi perkembangandan perdagangan yang terjadidibeberapa sektor seperti telekomunikasi, transportasi, dan jasa-jasa keuangan mengakibatkan adanya kompetisi di dalam lingkungan bisnis. Kekuatan kedua, kemunculan internet menyebabkan perkembangan teknologi informasi menjadi yang sangat cepat. Adanya perkembangan-perkembangan tersebut menyebabkan perubahan struktur bisnis dan menjadikan intangibles asset memiliki peran yang semakin penting bagi perusahaan. Perusahaan yang dikelola dengan baik dapat meningkatkan nilai perusahaan serta memajukan pertumbuhan perekonomian perusahaan. 
ISSN: 2302-8556

E-Jurnal Akuntansi Universitas Udayana Vol.24.2.Agustus (2018): 1274-1300

Guest (2003), Martina (2012), serta Awan dan Sarfraz (2013) menyatakan hasil penelitiannya bahwa untuk dapat memaksimalkan kinerja didalam perusahaan dilakukan dengan cara lebih meningkatkan kemampuan dan keterampilan yang merupakan bagian dari human capital. Tingginya nilai kapitalisasi pasar yang tercantum dalam laporan keuangan tahunan ditunjukkan dengan adanya komponen modal intelektual yang maksimal dalam perusahaan.Sedangkan, menurut penelitian yang dilakukan oleh Sunarsih (2012) dan Ramadan (2015), menyatakan bahwamodal intelektual (intellectual capital) tidak berpengaruh terhadap nilai. Setiap perusahaan menginginkan kinerja yang semakin meningkat. Selain sumber daya manusia yang menjadi pertimbangan bagi investor, Good Corporate Governance (GCG) juga merupakan faktor-faktor yang sangat diperhatikan oleh para investor untuk memberi penilaian kepada suatu perusahaan Susanto (2013). Berbagai hal dilaksanakan seperti mengimplementasikan tata kelola perusahaan yang baik (good corporate governance). Penerapan corporate governance yang berpedoman dengan aturan berlaku akan memberi pengaruh yang lebih kuat sebagai alat kontrol dari sumber daya manusia yang ada pada perusahaan dan berdampak pada nilai perusahaan yang semakin meningkat (Retno dan Priantinah, 2012).Khairandy dan Malik (2007) menyatakan perusahaan di Indonesia pada tahun 1998 yang pada masa kritis ekonomi telah mengalami kebangkrutan yang disebebkan oleh kurangnya praktik penerapan good corporate governance (GCG). Hal-hal yang menjadi penyebab kurangnya pelaksanaan good corporate governance (GCG) di perusahaan adalah terabaikannya hak minoritas, lemahnya standar akuntansi, pemeriksaan keuangan (auditing) yang 
kurang cakap, pengawasan komisaris yang kurang tegas, dan lemahnya hukum (Kusumawati dan Riyanto, 2005). Kurangnya penerapangoodcorporate governance dapat membuat melemahnya potensi perusahaan dan buruknya perusahaan dapat mengalami kesulitan finansial dan bahkan terjadi kecurangan. Hal tersebutapat diminimalkan dengan suatu mekanisme yang dapat mengkoordinir baik kepentingan para pemegang saham selaku pemilik maupun kepentingan selaku pengelola. Mekanisme tersebut dikenal dengan sebutan corporate governance (Ika Surya, 2003).

IICG memiliki tujuan untuk menyampaikan prinsip-prinsip good corporate governance serta manfaat penerapan good corporate governanceuntuk membentuk bisnis yang beretika di Indonesia.IICG melaksanakan program yang bernama Corporate Governance Perception Index (CGPI) untuk memberikan penghargaan atau penilaian terhadap perusahaan yang dapat mengungkapkan implementasi corporate governance yang baik yang dapat dihitung berdasarkan 4 taraf pengukuran, yaitu self assessment, system dokumentasi, penyusunan makalah, dan observasi. Corporate Governance Perception Index (CGPI) merupakansuatu program untukmelakukan pemeringkatan penerapan GCG pada perusahaan-perusahaan di Indonesia. Perusahaan yang mengikuti program CGPI tersebut diantaranya BUMN, Perusahaan Publik (Emiten), Perusahaan Swasta lainnya, dan Perbankan.Perusahaan yang telah terdaftar menjadi peserta dalam program Corporate Governance Perception Index (CGPI) yang dilakukan oleh The Indonesian Institute for Corporate Governance (IICG) secara tidak langsung akan menaikan nilai sahamnya karena telah menerapkan praktik GCG dengan efektif.Semakin baik implementasiterhadap GCG 
ISSN: 2302-8556

E-Jurnal Akuntansi Universitas Udayana Vol.24.2.Agustus (2018): 1274-1300

akan mendorong terbentuknya kinerja perusahaan yang semakin baik.Corporate Governance yang efekif akan memberikan rangsangan yang dapat digunakan untuk mencapai tujuan yang merupakan kepentingan perusahaan dan pemegang saham harus memfasilitasi pengawasan yang efektif sehingga mendorong perusahaan menggunakan sumber daya yang lebih efisien (Surya \& Yustiavandana, 2010).

Penelitian dilakukan untuk menguji kemampuan corporate governance dalam memediasi pengaruh human capital terhadap nilai perusahaan.Corporate governance yang diukur dengan CGPI diharapkan lebih mampu dalam merepresentasikan variabel corporate governance dibandingkan menggunakan pengukuran komponen dari corporate governance. Ketidakkonsistenan hasil dari penelitian terdahulu menjadikan topik penelitian ini menjadi penting dan menarik dengan menambah variabel mediasi, sehingga pemediasi dapatmempengaruh secara langsung maupun tidak langsung dari human capital pada nilai perusahaan.Pengertian corporate governance menurut Forum For Corporate Governance In Indonesia (FCGI) merupakan suatu sistem yang mengendalikan perusahaan dan mengatur hubungan yang ada didalamnya mengenai hak-hak dan kewajiban antara pemegang saham, pengelola perusahaan, pemerintah, karyawan, pihak kreditur, dan pemegang kepentingan lainnya.Berdasarkan hal tersebut, peneliti menguji kemampuan CG dalam memediasi pengaruh human capital pada nilai perusahaan.

Teori pada penelitian ini merupakan fungsi yang mendasar dalam pelaksaan proses penelitian. Teori dasar pada penelitian ini adalah Resourced Based Theory yang berasumsi bahwa sebuah organisasi dapat dinilai sebagai kumpulan dari sumber 
daya fisik, sumber daya manusia, dan sumber daya organisasi (Madhani, 2009). Human capital dapat meningkatkan value bagi perusahaan sehingga dianggap sebagai sumber daya yang memiliki kemampuan dalam memberikan keunggulan kompetitif perusahaan. Adanya keunggulan kompetitif yang dihasilkan oleh human capital didalam perusahaan mendorong terbentuknya penerapan strategi perusahaan yang baik sehingga terbentuknya kinerja perusahaan yang baik.

Konsep corporate governance wajib diterapkan oleh setiaporganisasi maupun perusahaan karena mampu memberikan kontribusi bagi kesejahteraan perusahaan maupun masyarakat. Penerapan corporate governance membentuk perusahaan untuk lebih transparan, bertanggungjawab, dan independen serta meningkatkan akuntabilitas perusahaan (Pedoman Umum Corporate Governance). Corporate governance memiliki peranan sebagai alat kontrol untuk semua pihak yang memiliki kepentingan dalam penerapan prinsip-prinsip corporate governance. Prinsip-rpinsip corporate governance dibagi menjadi 5 prinsip yang terdiri keterbukaan informasi (transparancy), akuntabilitas (accountability), pertanggung jawaban (responsibility), kemandirian (independency), dan kewajaran (fairness).

Pengukuran dan variabel yang digunakan dalampenelitian ini memiliki perbedaaan dengan penelitian yang dilakukan sebelumnya, sehingga diharapkan dapat memperoleh hasil yang lebih baik. Variabel human capital dalam penelitian ini diukur dengan HCE. Proksi tersebut menggunakan value added sebagai indikator yang objektif dalam menilai kesuksesan usaha dan menunjukkan potensi perusahaan dalam mewujudkan nlai pada perusahaan. Variabel nilai perusahaan diproksikan 
ISSN: 2302-8556

E-Jurnal Akuntansi Universitas Udayana Vol.24.2.Agustus (2018): 1274-1300

dengan ratio Tobin's $Q$. Nilai Tobin's Qmenggunakan penilaian dari 0 sampai 1 yang menunjukkan bahwa nilai pasar perusahaan lebih kecil dari biaya pergantian asset perusahaan. Nilai Tobin's Qlebih besar dari 1 memiliki arti nilai asset yang tercatat lebih kecil dibandingkan nilai pasar perusahaan. Variabel corporate governance diproksikan dengan indeks GCG yang dilakukan oleh IICG.

Teori yang digunakan dalam penelitian ini adalah Resources Based Theory (RBT). Teori RBT merupakan sebuah konsep yang mengkaji tentangcaraperusahaan untuk mengolah sumber daya yang dimiliki perusahaan untuk dapat dimanfaatkan dengan baik oleh perusahaan tersebut (Bontis, 2000). Teori RBT berasumsi perusahaan yang sanggup mengendalikan sumber daya yang dimilikinya dengan baik merupakan suatu cara untuk mendapatkan nilai tambah (value added), sehingga dengan bertambahnya nilai pada perusahaan akan berdampak pada peningkatan kinerja perusahaan. Human capital merupakan asset yang ada didalam perusahaan yang mampu memberikan atau menciptakan keunggulan kompetitif yang nantinya akan digunakan dalam menerapkan dan menyusun startegi perusahaan sehingga dapat menciptakan kinerja perusahaan yang baik. Berdasarkan hal tersebut jika sumber daya (human capital) di suatu perusahaan meningkat maka hal tersebut akan berdampak pada nilai perusahaan dengan adanya alat kontrol seperti corporate governance.

Corporate governance merupakan suatusistem atau alat kontrol yang dapat mengatur dan mengendalikan perusahaan sehingga dapat menciptakan nilai tambah bagi stakeholder (Monk dan Minow, 2003). Prinsip-prinsip corporate governance 
yang telah diterapkan oleh perusahaan digunakan untuk mengendalikan dan mengarahkan aktivitas didalam perusahaan agar operasional dan tindakan manajerial sejalan dengan tujuan perusahaan dan stakeholders.

Adanya penerapan corporate governance yang baik di suatu perusahaan, hal tersebut dapat mendorong terciptanya human capital yang lebih efisien sehingga dapat meningkatkan nilai pada perusahaan (Ika, 2003) . Hal ini terjadi karena dengan memperluas pengungkapan maka semakin memberikan lebih banyak informasi yang sifatnya menyeluruh dan dapat menjadi nilai tambah dalam suatu pelaporan keadaan perusahaan (Sir et al, 2010). Hipotesis yang dapat dibentuk dari penjalasan diatas adalah sebagai berikut:

$\mathrm{H}_{1}$ : Semakin efisien human capital maka semakin meningkat nilai perusahaan melalui corporate governance yang baik.

\section{METODE PENELITIAN}

Penelitian ini menggunakan pendekatan kuantitatif berbentuk asosiatif dengan tujuan untuk memperoleh informasi mengenai pengaruh antar dua variabel atau lebih (Sugiyono, 2014:6).Corporate governance sebagai pemediasi pengaruh human capital pada nilai perusahaan yang akan dibahas penelitian ini, sehingga desain penelitian ini seperti berikut:

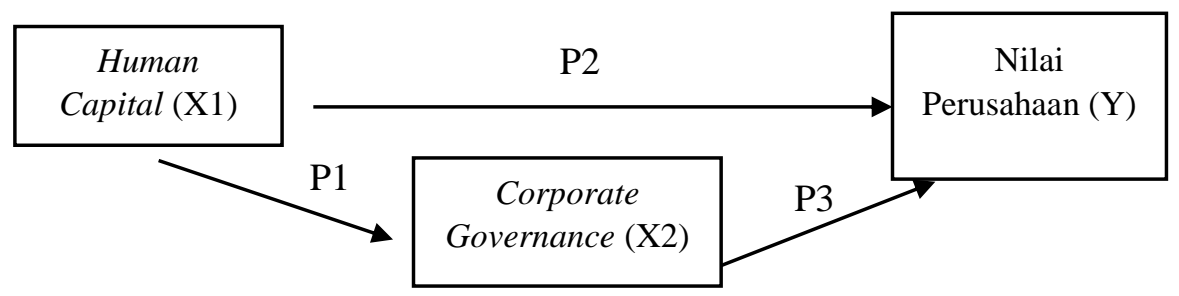

Gambar 1. Model Penelitian 
ISSN: 2302-8556

E-Jurnal Akuntansi Universitas Udayana Vol.24.2.Agustus (2018): 1274-1300

Variabel dependen (Y) adalah variabel yang dipengaruhi dan menjadi akibat dari adanya variabel independen(Sugiyono, 2014:59). Varibel terikat dalam penelitian ini adalah nilai perusahaan. Meningkatnya harga saham di sebuah perusahaan, hal tersebut berarti akan meningkatkan nilai perusahaan. White (2003) menyatakan pengukuran nilai perusahaan terdiri dari beberapa model, yaitu salah satunya menggunakan Tobin's Q ratio. Variabel independen (X) adalah variabel yang dapat mempengaruhi variabel dependen dan tidak dapat dipengaruhi oleh variabel lainnya (Sugiyono,2014:59). Terdapat satu variabel bebas yaitu human capital. Human capital diproksikan dengan Human Capital Efficiency yang dikambangkan oleh Pulic (2008). HCE merupakan suatu parameter untuk mengukur efisiensi biaya yang dikeluarkan sehingga kinerja karyawan menjadi meningkat dan dapat dapat menciptakan nilai bagi perusahaan. Variabel pemedasiyaitu variabel penghubung/variabel perantara yang berada diantara variabel bebas dengan variabel terikat (Sugiyono, 2014:61). Variabel pemediasi dalam penelitian ini adalah Good Corporate Governance (GCG) yang di proksikan dengan Corporate Governance Perception Index versi IICG. Untuk pengukuran gcg yang digunakan adalah skor dan indeks penilaian investor dari hasil program riset dan pemeringkatanCGPI. Penilaian penerapan corporate governance dengan menggunakan skordapat dibagi menjadi tiga tingkat kepercayaan yaitu pertama adalah 55-69 yang artinya cukup terpercaya, kedua adalah 70-84 yang artinya terpercaya, dan yang terakhir adalah 85-100 yang artinya sangat terpercaya. 
Populasi penelitian ini dilakukan di perusahaan teah terdaftar pada FCGI tahun 2009 sampai tahun 2016. Jenis data yang digunakan untuk penelitian yaitu data kuantitatif. Data kuantitatif berupa laporan keuangan perusahaan,harga saham di Bursa EfekIndonesia serta skor penerapanCorporate Governance Perception Index (CGPI).

Sumber data yang digunakan dalam penelitian adalah data sekunder, yaitu data yang diperoleh secara tidak langsung dari objek yang diteliti (Sumarsono, 2004). Untuk data laporan keuangan perusahaan di publikasikan oleh BEI pada tahun 20092016. Data laporan keuangan perusahaan diperolehdari situs www.idx.co.id. Data berupa harga saham penawaran di akses melalui situswww.idx.co.id. dan www.finance.yahoo.com. Data skor dari Corporate Governance Perception Index (CGPI) versi IICG didapat dari situs www.iicg.org.

Metode purposive sampling digunakan dalam penelitian ini untuk memilih kriteria sampel (Sugiyono, 2014). Untuk kriteria yang ditentukan adalahperusahaan yang telah terdaftar dan menjadi peserta dalam program CGPI yang dilakukan oleh IICG, Laporan keuangan tahunan yang berakhir pada tanggal 31 Desember. Teknik analisis yang digunakan yaitu analisis jalur (path analysis) menunjukkan adanya suatu variabel memiliki peran ganda. Peran ganda yang dimaksud yaitu variabel dapat berperan sebagai variabel bebas pada suatu signifikansi tetapi juga dapat menjadi variabel terikat pada signifikansi yang lain (Ghozali, 2016: 237). Program Statistical Package for Social Science (SPSS) digunakan dalam pengujian analisis. Rumus structural dari analisis jalur adalah sebagai berikut: 
Substruktural 1 yaitu hubungan antara X1 pada Y1

$$
\mathrm{Y} 1=\mathrm{b} 1 \mathrm{X} 1+\mathrm{e} 1
$$

Substruktural 2 yaitu hubungan antara X1, dan Y1 pada Y2

$$
\mathrm{Y} 2=\mathrm{b} 2 \mathrm{X} 1+\mathrm{b} 3 \mathrm{Y} 1+\mathrm{e} 2
$$

Hubungan yang menggambarkan pengaruh langsung dan pengaruh tidak langsung yang terdapat pada gambar 1. diatas.

Pengaruh langsung human capital kepada CG

$$
=\mathrm{p} 2 \text {. }
$$

Pengaruh tidak langsung (human capital terhadap CG, selanjutnya terhadap nilai perusahaan)

$$
=\mathrm{p} 1 \times \mathrm{p} 3 \ldots . .
$$

Penentuan variabel corporate governance sebagai variabel mediasi antara human capital dan nilai perusahaan ditentukan dengan membandingkan pegaruh langsung (1) dan tidak langsung (2) dari masing-masing variabel.

Sebelum melakukan uji analisi jalur, perlu dilakukan analisis uji asumsi klasik, hal tersebut dilakukan dengan tujuan mendapatkan kepastian dalam persamaan regresi yang memiliki ketepatan estimasi dan konsisten serta terbebas dari asumsiasumsi BLUE (Best, Linear, Unbias, dan Error). Pengujian normalitas yang digunakan adalah uji Kolmogorov-Smirnov (K-S) dan untuk pengujian heteroskedastisitas pada penelitian ini menggunakan uji spearman. Hasil dari persamaan regresi dinyatakan tidak terdapat heteroskedastisitas apabila koefisien variabel independen dengan residual memilikinilai signifikan melebihi nilai $(\alpha)$ sebesar 5\%. Uji autokeralasi yang digunakan yaitu uji Durbin-Watson (DW test). 
Penilai Goodness of Fit dengan cara melihat hasil koefisien determinasi atau r squaredan hasil uji $\mathrm{F}$ yangdigunakan untuk mengetahui kebenaran hipotesis dalam penelitian. Selain melaukan uji model tersebut, untuk dapat mengetahui pengaruh parsial antara variabel independen dengan variabel dependen haruslah dilakukan uji t statistik.

\section{HASIL DAN PEMBAHASAN}

Hasil dari penentuan sampel yang dianalisis dengan metodepurposive sampling dapat dilihat pada Tabel 1 .

\begin{tabular}{ccc}
\multicolumn{2}{c}{ Tabel 1. } \\
Hasil Seleksi Sampel \\
\hline No & Kriteria Sampel & Jumlah \\
\hline 1. & Perusahaan yang terdaftar di FCGI & 41 \\
2. & $\begin{array}{l}\text { Perusahaan yang tidak mengeluarkan skor GCG pada CGPI berturut- } \\
\text { turut }\end{array}$ & $(33)$ \\
3. & Perusahaan yang tidak mengeluarkan laporan keuangan & - \\
\hline Jumlah perusahaan yang menjadi sampel & 8 \\
\hline
\end{tabular}

Tabel 1. menunjukkan bahwa 8 perusahaan telah dipilih menjadi sampel penelitian dengan kriteria yang telah ditentukan. 50\% industri yang mendominasi sampel penelitian ini ialah industri perbankan. Industri lainnya yang memiliki persentase dibawah $50 \%$ yaitu pertambangan, asuransi, telekomunikasi dan transportasi. 
ISSN: 2302-8556

E-Jurnal Akuntansi Universitas Udayana

Vol.24.2.Agustus (2018): 1274-1300

Tujuan dari statistik deskriptif yaitu untuk mendeskripsikan dan menerangkan data mengenai speifikasi darihasil penelitian yang terdiri atas banyaknya pengamatan, nilai minimal, nilai maksimal, nilai rata-rata, dan nilai standar deviasi. Untuk hasil uji statistik deskriptif dapat dilihat pada Tabel 2.

Tabel 2.

Hasil Uji Statistik Deskriptif

\begin{tabular}{lrrrrr}
\hline \multicolumn{1}{c}{ Variabel } & N & Minimal & Maksimal & Mean & \multicolumn{1}{c}{$\begin{array}{c}\text { Std. } \\
\text { Deviation }\end{array}$} \\
\hline Human capital & 64 & 0,10 & 4,88 & 3,1097 & 0,95531 \\
Corporate & 64 & 75,00 & 93,32 & 85,3917 & 3,82582 \\
governance & & & & & \\
\hline Nilai perusahaan & 64 & 0,67 & 3,85 & 2,3917 & 0,65164 \\
\hline
\end{tabular}

Sumber: Data diolah, 2017

Human capital yang dihitung dengan HCE memiliki nilai minimum sebesar 0,10yaitu perusahaan Aneka Tambang Tbk (ANTM) pada tahun 2015, nilai maksimum sebesar 4,88oleh perusahaan Bukit Asam (PTBA) pada tahun 2011. Nilai rata-rata sebesar 3,1097 dan nilai standar deviasi human capital sebesar 0,95531, sehingga sebarannya berkisar diantara 2,15439 sampai 4,06501. Hasil tersebut diperoleh dari 3,1097 $\pm 0,95531$, yang artinya sebaran data human capital tersebar dengan merata. Untuk nilai range pada human capital adalah senilai 4,78.

Rata-rata skor corporate governance ialah sebesar 85,3917. Artinya rata-rata skor penilaian corporate governance pada perusahaan yang terdaftar di FCGI memiliki tingkat kepercayaan sebesar 85. Penelitian ini memiliki tingkat kepercayaan paling tinggi sebesar 93,32 terjadi pada Bank Mandiri (BMRI) pada tahun 
pengamatan 2016 dan yang memiliki tingkat kepercayaan yang rendah sebesar 75,00ialah Jasa Marga Tbk (JSMR) pada tahun 2010. Nilai standar deviasi corporate governance sebesar 3,82582, sehingga sebarannya berkisar diantara 81,56588 sampai 89,21752 . Hasil tersebut diperoleh dari $85,3917 \pm 3,82582$, yang artinya sebaran data corporate governance tersebar dengan merata. Untuk nilai range pada corporate governance adalah senilai 18,32 .

Nilai perusahaan dihitung dengan menggunakan rumus tobins $Q$ memiliki nilai minimum sebesar 0,67 yaitu perusahaan Aneka Tambang Tbk (ANTM) di tahun pengamatan 2012 dan nilai maksimum sebesar 3,85oleh perusahaan Bukit Asam Tbk (PTBA) tahun 2009. Nilai rata-rata nilai perusahaan adalah sebesar 2,3917. Nilai standar deviasi nilai perusahaansebesar 0,65164, sehingga sebarannya berkisar diantara 1,74006 sampai 3,04334. Hasil tersebut diperoleh dari 2,3917 $\pm 0,65164$, yang artinya sebaran data nilai perusahaantersebar dengan merata. Untuk nilai range pada nilai perusahaanadalah senilai 3,18 .

Sebelum digunakan uji kelayakan model untuk memprediksikan, dilakukan uji asumsi klasik terlebihdahulu. Uji dilakukan antara lain uji normalitas, heteroskedastisitas dan autokorelasi. Uji normalitas diukur menggunakan uji Kolmogorov-Smirnov berfungsi untuk menguji apakah variabel terdistribusi normal atau tidak. Data dianggap terdistribusi normal, apabila memiliki nilai signifikan melebihi nilai $\alpha=0,05$ (Ghozali, 2016:147).

Uji normalitas yang tampak pada Tabel 3. menunjukkan nilai K-S sebesar 0,600 dan nilai Asymp. Sig. (2-tailed) memiliki nilai diatas dari nilai $\alpha=5 \%$, sehingga 
ISSN: 2302-8556

E-Jurnal Akuntansi Universitas Udayana

Vol.24.2.Agustus (2018): 1274-1300

data dapat dikatakan berdistribusi secara normal.

Tabel 3.

Hasil Uji Normalitas

\begin{tabular}{lr}
\hline & Unstandardized Residual \\
\hline Kolmogorov-Smirnov Z & 0,600 \\
\hline Asymp. Sig. (2-tailed) & 0,865 \\
\hline Sumber :data diolah, 2017 &
\end{tabular}

Uji heteroskedastisitas dilakukan melalui metode Spearman dengan tujuan untuk mengetahui apakah pada model regresi terdapat ketidaksamaan variansi dari residual pengamatan satu ke pengamatan lainnya. Jika nilai Sig. (2-tailed)memiliki nilai lebih dari alpha 5\%dapat dijelaskan bahwa model regresi ini tidak mengandung masalah heteroskedastisitas dan model regresi dapat dikatakan baik. Tabel 4. menunjukkan hasil uji heteroskedastisitas pada masing-masing variabel memiliki nilai Sig. (2-tailed) lebih dari 5\% dikatakan terbebas dari heteroskedastisitas.

\section{Tabel 4.}

Hasil Pengujian Heteroskedastisitas

\begin{tabular}{ccl}
\hline Variabel & Sig. (2-tailed) & \multicolumn{1}{c}{ Keterangan } \\
\hline Human Capital & 0,428 & Bebas Heteroskedastisitas \\
Corporate Governance & 0,260 & Bebas Heteroskedastisitas \\
& & \\
\hline
\end{tabular}

Sumber :data diolah, 2017

Uji autokorelasi dapat dilihat dari nilai Durbin-Watson (DW), untuk mengetahui ada tidaknya korelasi antara variabel pada periode tertentu dengan variabel periode sebelumnya. Model regresi yang baik seharusnya tidak terjadi autokorelasi. Tabel 5. menunjukkan hasil uji autokorelasi dengan nilai DW sebesar 
2,139, dengan nilai dan $\mathrm{dU}=1,66011$ dan nilai $4-\mathrm{dU}=4-1,66011=2,33989$. Nilai statistik 2,139 berada diantara dU dan 4-dU $(1,66011<2,139<2,46848)$ maka pengujian dengan Durbin-Watson dapat dikatakan tidak terjadi gejalas autokrelasi.

Tabel 5.

Hasil Pengujian Autokorelasi

\begin{tabular}{cccc}
\hline \multirow{2}{*}{ Model } & Adjusted R Square & Std. Error of the & Durbin- \\
& 0,086 & Estimate & Watson \\
\hline 1 & & 0,62303 & 2,139 \\
\hline
\end{tabular}

Sumber :data diolah, 2017

Hasil pengujian persamaan regresi substruktural 1 ditunjukkan oleh Tabel 6. Untuk pengaruh langsung. Tabel 6. variabelhuman capital menunjukkan nilai pvalue sebesar 0,155 lebih besar dari 0,05 yang berarti human capital tidak berpengaruh terhadap corporate governance. Memiliki nilai Adjusted $R$ Square 0,017 yang berarti variabel corporate governance dapat dijelaskan oleh human capitalsebesar 1,7\% dan 98,3\% sisanya dipengaruhi oleh variabel lain yang tidak masuk dalam model.

\section{Tabel 6.}

Hasil Pengujian Persamaan 1

\begin{tabular}{|c|c|c|c|c|c|}
\hline \multirow[b]{2}{*}{ Model } & \multicolumn{2}{|c|}{$\begin{array}{l}\text { Unstandardized } \\
\text { Coefficients }\end{array}$} & \multirow{2}{*}{$\begin{array}{c}\text { Standardized } \\
\text { Coefficients } \\
\text { Beta } \\
\end{array}$} & \multirow[b]{2}{*}{$\mathbf{T}$} & \multirow[b]{2}{*}{ Sig. } \\
\hline & B & Std. Error & & & \\
\hline $1 \quad$ (Constant) & 87,629 & 1,627 & & 53,875 & 0,000 \\
\hline human capital & $-0,720$ & 0,500 & $-0,180$ & $-1,438$ & 0,155 \\
\hline Adjusted R Square & 0,017 & & & & \\
\hline
\end{tabular}

Hasil pengujian persamaan regresi substruktural 1 ditunjukkan oleh Tabel 7. untuk pengaruh tidak langsung. Tabel 7. Menunjukkan uji Fyang diperoleh sebesar 3,983 dengan nilai pvalue 0,024 lebih kecil dari 0,05. Nilai Adjusted $R$ Square sebesar 0,086 yang berarti bahwa 8,6\% nilai perusahaan dipengaruhi oleh human 
ISSN: 2302-8556

E-Jurnal Akuntansi Universitas Udayana

Vol.24.2.Agustus (2018): 1274-1300

capital dan corporate governance dan sisanya 91,4\% dipengaruhi oleh variabel lain yang adadiluar model seperti profitabilitas, ukuran perusahaan, CSR, struktur kepemilikan modal dan lain-lain. Nilai koefisien regresi variabel human capital sebesar 0,206 dengan nilai pvalue sebesar 0,016 lebih kecil dari 0,05 yang berarti human capital berpengaruh positif signifikan secara langsung pada nilai perusahaan. Nilai koefisien regresi variabel corporate governance sebesar -0,019 dengan nilai pvalue sebesar 0,377 lebih kecil besar dari 0,05. Hasil tersebut menunjukkan bahwa variabel corporate governance tidak mempengaruhi hubungan variabel human capital terhadap nilai perusahaan. Berdasarkan hal tersebut hipotesisdalam penelitian ini ditolak.

Tabel 7.

Hasil Pengujian Persamaan 2

Unstandardized Standardized

Coefficients Coefficients

Model

Std.

\begin{tabular}{|c|c|c|c|c|c|c|}
\hline & & B & Error & Beta & $\mathbf{T}$ & Sig. \\
\hline \multirow[t]{5}{*}{1} & (Constant) & 3,335 & 1,847 & & 1,805 & 0,076 \\
\hline & human capital & 0,206 & 0,084 & 0,302 & 2,467 & 0,016 \\
\hline & Corporate governance & $-0,019$ & 0,021 & $-0,109$ & $-0,889$ & 0,377 \\
\hline & Adjusted $R$ Square & 0,086 & & & & \\
\hline & Uji F & 3.960 & & & & 0,024 \\
\hline
\end{tabular}

Sumber :data diolah, 2017 
Hasil uji hipotesis yang tampak pada Gambar 2. dibawah, dapat dilihatnilai pengaruh langsung dan pengaruh tidak langsung dari masing-masing variabel. Koefisien pengaruh langsung variabel human capital pada corporate governance senilai $-0,720$. Koefisien pengaruh langsung variabel corporate governance padanilai perusahaan sebesar -0,019 dan Koefisien pengaruh langsung variabel human capital pada nilai perusahaansenilai -0,206. Koefisien pengaruh tidak langsung variabel human capital pada nilai perusahaan melalui corporate governance menunjukkan hasil $0,014(-0,720 \times-0,019)$.

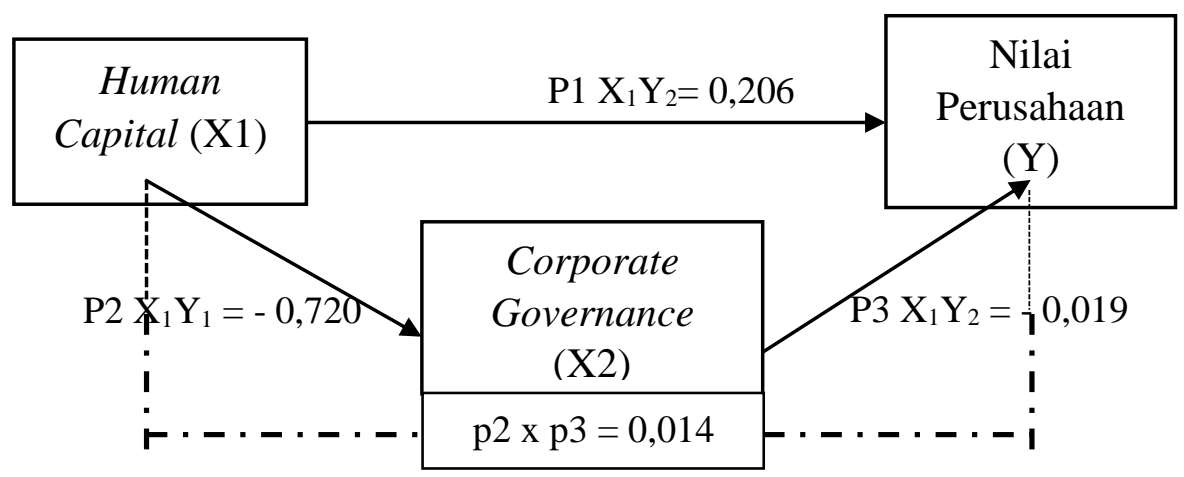

Gambar 2. Model Jalur human capital pada nilai perusahaan melalui corporate governance sebagai pemediasi

Hasil analisis jalur pada Gambar 2.menunjukkan bahwa pengaruh tidak langsung dari human capital terhadap nilai perusahaan melalui corporate governance adalah 0,014 lebih kecil dari pengaruh langsung variabel human capital terhadap niai perusahaan senilai 0,206. Berdasarkan hasil tersebut menunjukkan bahwa corporate governance tidak dapat memediasi hubungan antara human capital pada nilai perusahaan, sehinggah hipotesis pada penelitia ini ditolak. 
ISSN: 2302-8556

E-Jurnal Akuntansi Universitas Udayana Vol.24.2.Agustus (2018): 1274-1300

Hasil pengujian pertama mengenai pengaruh human capital terhadap nilai perusahaan menunjukkan hasil yang signifikan. Artinya bahwa perusahaan yang memiliki human capital yang berkualitas akan dapat menciptakan value added yang semakin tinggi maka dapat berpengaruh dalam peningkatakan kinerja perusahaan. Hasil penelitian konsisten dengan penelitian yang dilakukan oleh Ulum et al (2008), Simarmata (2015), Puspita (2012) dan Widarjo (2011) yang melakukan penelitian tentang pengaruh modal intelektual terhadap nilai perusahaan. Semakin tinggi value added yang dapat diciptakan, menandakan bahwa perusahaan telah mengelola modal manusianya dengan baik sehingga dapat meningkatkan nilai perusahaan. Hasil penelitian juga konsisten dengan resourced based theory yang menyatakan bahwa perusahaan harus melakukan pengelolaan terhadap karyawannya dengan tujuan karyawan tersebut tidak meninggalkan perusahaan dan dapat memaksimalkan kinerjanya. Ketika human capital telah diterapkan secara efisien dalam perusahaan, maka secara tidak langsung akan menciptakan nilai perusahaan yang lebih baik. Berdasarkan konsep resource-based theory, karyawan adalah aset penting dalam perusahaan karena pengetahuan dan keterampilan yang dimiliki dapat mejadi kompetensi perusahaan untuk dapat bersaing dengan perusahaan-perusahaan lainnya. Penelitian ini bertentangan dengan hasil penelitianAbdolmohamadi (2005), Octaviany (2015), Sunarsih (2012) menyatakan hasil yang berbeda. Hasil penelitian menunjukkan bahwa human capitalberpengaruh pada nilai perusahaan. 
Hasil pengujian kedua menyatakan bahwa human capital tidak berpengaruh pada nilai perusahaan melalui corporate governance, sehingga hipotesis dalam penelitian ini ditolak. Hasil penelitian konsisten dengan penelitian yang dilakukan oleh Sitorus (2013), Ratih (2011) dan Amy pramanda (2014), yang menyatakan bahwa corporate governance secara langsung tidak memiliki pengaruh terhadap nilai perusahaan. Hasil penelitian ini tidak dapat menunjukkan bahwa corporate governance dapat memediasi pengaruh human capital terhadap nilai perusahaan. Penelitian dari Cahyani (2012)yang menyatakan dengan munculnya kasus PT. Timah dan Bank BNI yang telah terpilih dalam peringkat 10 besar tetapi menimbulkan kemunduran kinerja pada tahun berikutnya yang menyebabkan investor belum sepenuhnyadapat mempercayai hasil survei CGPI.

Berdasarkan hal tersebut IICG terus berusaha agar CGPI dapat diyakini dan dapat dijadikan sebagai parameter untuk investor dalam mengambil keputusan investasi. Hal tersebut diakibatkan dari tidak adanya perangkat corporate governance untuk mengawasi keahlian dan inovasi yang dihasilkan oleh karyawan. Untuk mengukur keahlian dan kinerja karyawan tidak seperti laporan keuangan yang secara periodik dapat dievaluasi. Corporate governance sebagai variabel mediasi belum mampu memperlihatkan bahwapara investor sangat mengamati informasi mengenai corporate governance, sehingga dipandang tidak memiliki nilai ekonomis lebih yang bisa diciptakan dari perolehan peringkat "The Indonesia Most Trusted Companyberdasarkan CGPI" tersebut. 
ISSN: 2302-8556

E-Jurnal Akuntansi Universitas Udayana

Vol.24.2.Agustus (2018): 1274-1300

\section{SIMPULAN}

Berdasarkan hasil penelitian dan pengujian hipotesis, dapat ditarik kesimpulan dalam penelitian ini adalah sebagai berikut. Human capitalmemiliki pengaruh yang signifikan tehadap nilai perusahaan. Perusahaan yang dapat mengelola modal manusia atau human capital dengan baik akan dapat meningkatkan nilai perusahaan, karena ketika perusahaan dapat mengelola human capital dengan efisien maka semakin tinggi value added yang dapat diciptakan, dan akan berdampak pada peningkatan nilai perusahaan.Investor yang menyadari bahwa human capital yang dikendalikan dengan baik dalam sebuah perusahaan, dapat menyebabkan meningkatnya penilaian pasar terhadap perusahaan tersebut. Perusahaan menganggap karyawan adalah sumber daya kunci perusahaan.

Hasil penelitian tidak mampu membuktikan bahwa corporate governance mampu memediasi human capital terhadap nilai perusahaan. Corporate governance sebagai tata kelola perusahaan dalam penelitian menyatakan belum mampu secara optimal diterapkan oleh perusahaan, sehingga penilaian dari corporate governance hanya dipandang sebagai formalitas saja untuk menarik perhatian investor dan masyarakat.Investor belum sepenuhnya mempercayai hasil penilaian terhadap good corporate governance yang dilakukan oleh IICG dan investor belum mampu memberikan penghargaan terhadap perusahaan yang telah terdaftar dan menjadi peserta dalam program CGPI. Berdasarkan hal tersebut implementasi corporate governance secara langsung membutuhkan waktu untuk dapat direspon oleh pasar. 
Keterbatasan jumlah sampel dalam penelitian mengakibatkan hipotesis ditolak, untuk memperbaiki penelitian selanjutnya diharapkan menggunakan pengukuran corporate governance yang lain agar tidak terbatas pada perusahan go publicyang telah mendaftarkan diri dengan sukarela dalam program CGPI.Disarankan melakukan observasai secara langsung ke perusahaan-perusahaan sehingga sampel yang didapat menjadi lebih banyak dan tidak berpatokan pada perusahaan-perusahaan yang menjadi peserta dalam program tersebut dan dapat menggunakan perusahaan dengan sektor atau bidang tertentu, seperti perbankan, manufaktur, pertambangan ataupun sektor lainnya. Penelitian selanjutnya dapat menggunakan variabel pemediasi lainnya sekiranya akan menambah variasi hasil dari pengaruh human capital pada nilai perusahaan.

\section{REFERENSI}

Abdolmohamadi, Mohamad J. 2005. Intellectual Capital Disclosure and Market Capitalization. Journal of Intellectual Capital.Vol .6 No.3 pp 397-417.

Awan, M.A.S dan N. Sarfraz. 2013. The Impact of Human Capital on Company Performance and the Mediating Effect of Employee's Satisfaction. IOSR Journal of Business and Management.8(2): 76-83.

Barney, J.B. 1986. Organizational Culture: Can It Be A Source of Sustained Competitive Advantage? Academy of Management Review. Vol. 11: pg.656665.

Bontis, Nick. 2000. "Assessing Knowledge Assets: A Review of the Models Used to Measure Intellectual Capital”. Closing Keynote Presentation, KM World 2000.

Cahyani. 2012. Pengaruh Corporate Governance Perception Index Terhadap Kinerja Peusahaan Pada Perusahaan Yang Terdaftar Di Bursa Efek Jakarta. Jurnal Bisnis dan Ekonomi. ISSN: 1412-3126. Vol. 16 No. 2. 
ISSN: 2302-8556

E-Jurnal Akuntansi Universitas Udayana Vol.24.2.Agustus (2018): 1274-1300

Ghozali, Imam. 2016. Aplikasi Analisis Multivariate Dengan Program IBM SPSS 23. Edisie 8. Semarang: Badan Penerbit Universitas Diponegoro.

Ika Surya Martsila, Wahyu Meiranto, "Pengaruh Corporate Governance terhadap Kinerja Keuangan, "Journal of Accounting,Vol. 2:4 (2003), hlm. 1.

Keown, Arthur J. Martin, John. Petty, J. William. Scott Jr, David. 2011. Manajemen Keuangan: Prinsip dan Penerapan. Edisi Kesepuluh. Jakarta:Salemba Empat.

Kuryanto, B. dan Syafruddin, M. 2008. Pengaruh Modal Intelektual Terhadap Kinerja Perusahaan. Simposium Nasional Akuntansi 11 (SNA 11), 23-24 Juli 2008.

Kusumawati. D. N. dan Riyanto. 2005. Corporate Governance dan Kinerja: Analisis Pengaruh Compliance Reporting dan Struktur Dewan terhadap Kinerja Perusahaan. MakalahSimposium Nasional Akuntansi VIII.

Martina. 2012. Dampak Set Peluang Investasi Terhadap Nilai Perusahaan Publik di Bursa Efek Indonesia. JAAI. Vol. 9. No. 117-126.

Mayo, A., 2000. "The Role of Employee Development in The Growth ofIntellectual Capital”, Personal Review, Vol. 29, No. 4.

Monks, R A.G dan Minow, N. 2003. Corporate Governance 3rd Edition, Blackwell Publishing

Nurlela, Rika dan Islahuddin. 2008. Pengaruh Corporate Social Responsibility Terhadap Nilai Perusahaan dengan Prosentase Kepemilikan Manajemen Sebagai Variabel Moderating, Simposium Nasional Akuntansi XI Pontianak.

Octaviany G., Issabella. 2015. Pengaruh Intellectual Capital Disclosur Terhadap Nilai Perusahaan Dengan Good Corporate Governance Sebagai Variabel Moderasi. Jurnal TEKUN. Vol. VI/. No. 01. pp 96-111

Pornpen, Thippayana. 2014. Determinants of Capital Structure in Thailand. Procedia-Sosial and Behavioral Sciences, 143: pp: 1074-1077

Pulic, A. 2008. Measuring the Performance of Intellectual Potential in Knowledge Economy. Paper Presented at the 2nd Mcmaster Word Congress on Measuring and Managing Intellectual Capital by the Austrian Team for Intellectual Potential.

Ramadan, Imad Zeyad. 2015. Leverage ang the Jordarian Firm'Value Empirical Evidence. International Journal of Economic and Finance. 7 (4): pp: 75-81. 
Rasyid, Abdul. 2015. Effectss of Ownership Structure, Capital Structure, Profitability and Company's Growth Towards Firm Value. Internastional Journal Of Bussiness and Management Investion, 4(4): pp: 24-30.

Ratih, Suklimah. 2011. Pengaruh Good Corporate Governance terhadap Nilai Perusahaan dengan Kinerja Keuangan sebagai Variabel Intervening pada Perusahaan Peraih The Indonesia Most Trusted Company-CGPI. Jurnal Kewirausahaan. Vol. 5. No. 2. Pp. 18-24.

Retno, M. \& Partinah, D. 2012. Pengaruh Corporate Social Responsibility Dan Good Corporate Governance Pengungkapan Terhadap Nilai Perusahaan. Simposium Nasional AkuntansiXIII, Purwokerto.

Sartono, Agus. 2002. Manajemen Keuangan Teori dan Aplikasi. Yogyakarta: BPFE.

Sir, J., Chandrarin dan Subroto. 2010. Intellectual Capital dan Abnormal Return (Studi Peristiwa Pada Perusahaan Publik di Indonesia). Simposium Nasional Akuntansi XIII. Purwokerto: 7-9 November.

Sitorus, Tigor., Tivia Venica T. Sitorus., and Edoardus Satya Adhiwardana. Corporate Socia Responsibilit as Mediating Variable on Good Corporate Governance Influences toward Corporate Value: Empirical Study at Indonesian Government Bank Listed in Indonesian Stock Exchange, 2012. Proceedings of 23rd International Business Research Conference. 18-20 November 2013. Australia.

Sudiyatno, Bambang, Elen Puspita Sari dan Andi Kartika. 2012. The Company's Policy, Firm Performance, and Firm Value: An Empirical Research on Indonesia Stock Exchange. American Internastional Journal of Contemporary Research. 2 (12).

Sugiyono. 2014. Metode Penelitian. Bandung: Alfabeta.

Sunarsih, Ni Made dan Ni Putu Yuria Mendra. 2012. "Pengaruh Modal Intelektual Terhadap Nilai Perusahaan Dengan Kinerja Keuangan Sebagai Variabel Intervening Pada Perusahaan Yang Terdaftar Di Bursa Efek Indonesia." Simposium Nasional Akuntansi XV. Banjarmasin.

Susanto M dan Juniarti. 2013. Pengaruh Penerapan Good Corporate GovernancePada Variabel Debt Ratio, Ukuran, dan Sektor Industri Terhadap Nilai Perusahaan. Busines Accounting Review. Vol. 1, No. 2. 
ISSN: 2302-8556

E-Jurnal Akuntansi Universitas Udayana

Vol.24.2.Agustus (2018): 1274-1300

Tjiptohadi Sawarjuwono dan Agustine Prihatin Kadir, "Intellectual Capital: Perlakuan Pengukuran dan Pelaporan (Sebuah Library Research)," Jurnal Akuntansi dan Keuangan, No. 1, Vol. 5, (Mei 2003), hlm. 36.

Ulum, I., Ghozali, I., \& Chairi, A. 2008. Intellectual Capital dan Kinerja Perusahaan: Suatu Analisis dengan Pendekatan Partial Least Squares. Simposium Nasional AkuntansiXI

Weatherly, L.A. 2003. "The Value of People: The Challenges and Opportunities of Human Capital Measurement and Reporting," dalam Research Quarterly. Society for Human Resource Management.

White. (2003). Analisis Pengaruh Pengungkapan Informasi Pertanggungjawaban Sosial terhadap Firm Value Pada Perusahaan Manufaktur Di Indonesia. Simposium Nasional AkuntansiVII, Surabaya.

Widarjo, W. 2011. Pengaruh Modal Intelektual dan Pengungkapan Modal Intelektual pada Nilai Perusahaan. Simposium Nasional Akuntansi XIV. Aceh 